\title{
O035. Headaches in Mitochondrial Disorders
}

\author{
Catello Vollono $^{1 *}$, Giudo Primiano ${ }^{1}$, Anna Losurdo ${ }^{2}$, Serenella Servidei ${ }^{1}$, Giacomo Della Marca ${ }^{1}$ \\ From Abstracts from the 1st Joint ANIRCEF-SISC Congress \\ Rome, Italy. 29-31 October 2015
}

\section{Background}

Headaches are a well known feature of Mitochondrial Disorders (MCDs). However, no systematic epidemiological data are available in large populations of patients.

We aimed to describe the prevalence and the characteristics of headache in a large group of patients with mitochondrial encephalomyopathies.

\section{Methods}

We studied all consecutive patients referred to our Neuromuscular Unit, during a 6-month period. Ninetythree patients (aged 15 to 78 years, 31 males) with a typical phenotype of MCDs, underwent a structured diagnostic headache interview, using an operational diagnostic tool following the IHS criteria. If they met the criteria for primary headache, they were included in the "Headache Group" (HEAD+). The other patients were collected in the "No Headache Group" (HEAD-). Clinical, neuroradiological, and neurophysiological data were compared between groups. Mann-Whitney U-test was used to analyze numeric variables; Fisher's exact test was used to analyze nominal variables. Binary logistic regression analysis was performed to identify risk factors of headache.

\section{Results}

Headaches were reported in $35.48 \%$ of patients. Migraine was the most common headache. The patients of the Headache Group were younger (HEAD $+=45.5 \pm$ 17.2 years; $\mathrm{HEAD}-=54.5 \pm 14.8$ years; $\mathrm{U}$-test $=7.393$; $\mathrm{p}=0.007)$, increased prevalence of epilepsy $(\mathrm{p}=0.0103)$, myoclonus ( $\mathrm{p}=0.0309)$, stroke $(\mathrm{p}=0.0290)$, EEG focal slow abnormalities $(p=0.0359)$, EEG epileptic focal abnormalities $(p=0.0425)$, and decreased prevalence of muscle weakness $(p<0.0001)$ and EEG normal pattern

\footnotetext{
* Correspondence: Ivol@libero.it

'Unit of Neurophysiopathology and Sleep Medicine, Department of

Geriatrics, Neurosciences and Orthopedics, Catholic University, Rome, Italy
}

Full list of author information is available at the end of the article $(\mathrm{p}=0.0136)$. Multivariate analysis showed that HEAD+ was significantly associated with absence of muscle weakness $(\mathrm{CI}=1.007-14.894 ; \mathrm{p}=0.049)$ and EEG abnormalities $(\mathrm{CI}=1.347-78.085 ; \mathrm{p}=0.025)$.

\section{Conclusions}

Migraine has a higher prevalence in MCDs compared to population-based data. Our findings are consistent with the widely hypothesized role of mitochondria in the migraine pathophysiology.

Written informed consent to publication was obtained from the patient(s).

\section{Authors' details}

${ }^{1}$ Unit of Neurophysiopathology and Sleep Medicine, Department of Geriatrics, Neurosciences and Orthopedics, Catholic University, Rome, Italy. ${ }^{2}$ Istituto Auxologico Italiano, Department Neurology, S. Luca Hospital, Milan, Italy.

Published: 28 September 2015

doi:10.1186/1129-2377-16-S1-A68

Cite this article as: Vollono et al:: O035. Headaches in Mitochondrial Disorders. The Journal of Headache and Pain 2015 16(Suppl 1):A68.

\section{SpringerOpen ${ }^{\circ}$}

(c) 2015 Vollono et al. This is an Open Access article distributed under the terms of the Creative Commons Attribution License (http:// creativecommons.org/licenses/by/4.0), which permits unrestricted use, distribution, and reproduction in any medium, provided the original work is properly cited. The Creative Commons Public Domain Dedication waiver (http://creativecommons.org/publicdomain/ zero/1.0/) applies to the data made available in this article, unless otherwise stated.
Submit your manuscript to a SpringerOpen ${ }^{\bullet}$ journal and benefit from:

- Convenient online submission

- Rigorous peer review

- Immediate publication on acceptance

- Open access: articles freely available online

- High visibility within the field

- Retaining the copyright to your article

Submit your next manuscript at $>$ springeropen.com 